\title{
A case report of myocarditis combined with hepatitis caused by herpes simplex virus
}

\author{
Tetsuya Yamamoto ${ }^{1}$, Tsuneaki Kenzaka ${ }^{1,2^{*}}$ (D, Masanori Matsumoto ${ }^{1}$, Ryo Nishio ${ }^{1,2}$, Satoru Kawasaki ${ }^{1}$
} and Hozuka Akita ${ }^{1}$

\begin{abstract}
Background: Viral myocarditis presents with various symptoms, including fatal arrhythmia and cardiogenic shock, and may develop into chronic myocarditis and dilated cardiomyopathy in some patients. We report a case of viral myocarditis and hepatitis caused by herpes simplex virus.

Case presentation: A 20-year-old woman was admitted to our hospital with fever, fatigue, and anorexia. The initial investigation showed elevated liver enzyme levels and elevated creatine phosphokinase, and computed tomography showed diffuse swelling and internal heterogeneous image in the liver. These findings were consistent with acute hepatitis; therefore, we performed a liver biopsy, which showed parenchymal necrosis and lymphocytic infiltration. The night that the liver biopsy was performed, blood pressure gradually decreased and revealed cardiogenic shock. Electrocardiography showed diffuse ST-segment elevation, and echocardiography showed a dilated, spherical ventricle with reduced systolic function and pericardial effusion. An endomyocardial biopsy revealed lymphocyte infiltration of the myocardium, confirming acute myocarditis. After a few days, tests for immunoglobin $\mathrm{M}$ and immunoglobin $\mathrm{G}$ antibodies against herpes simplex virus were positive.

Conclusions: We presented a rare case of myocarditis combined with hepatitis that was caused by herpes simplex virus. Acute myocarditis can occur concurrently with hepatitis, pancreatitis, nephritis, and encephalitis; thus, determining the presence of other infectious lesions is necessary to provide appropriate treatment for the patient.
\end{abstract}

Keywords: Myocarditis, Hepatitis, Herpes simplex virus, Case report

\section{Background}

Myocarditis can present with various symptoms, ranging from mild dyspnea to chest pain, cardiogenic shock, and fatal arrhythmia. The main cause of myocarditis is current or recent viral infection [1]. Enteroviruses, specifically Coxsackievirus $(\mathrm{CV})$ group B serotypes, have traditionally been perceived as the predominant viral cause [2], although adenoviruses, parvovirus B19, and human herpes virus 6 can also cause myocarditis [3-5]. In contrast,

\footnotetext{
*Correspondence: smile.kenzaka@jichi.ac.jp

1 Department of Internal Medicine, Hyogo Prefectural Kaibara Hospital,

5208-1, Kaibara, Kaibara-cho, Tanba, Hyogo 669-3395, Japan

${ }^{2}$ Division of Community Medicine and Career Development, Kobe University

Graduate School of Medicine, 2-1-5, Arata-cho, Hyogo-ku, Kobe, Hyogo 652-0032, Japan
}

herpes simplex virus (HSV) rarely causes acute myocarditis. A few case reports described that viral myocarditis may be combined with hepatitis, pancreatitis, nephritis, and encephalitis [6-8].

We encountered a case of combined myocarditis and hepatitis caused by HSV infection.

\section{Case presentation}

A 20-year-old woman, who had an unremarkable medical history and was immunocompetent, was admitted to another hospital due to fever, fatigue, and anorexia, and she was administered acetaminophen and antibiotics. She also experienced vomiting, as well as systemic myalgia 5 days after admission causing an inability to move.

(c) The Author(s). 2018 Open Access This article is distributed under the terms of the Creative Commons Attribution 4.0 International License (http://creativecommons.org/licenses/by/4.0/), which permits unrestricted use, distribution, and reproduction in any medium, provided you give appropriate credit to the original author(s) and the source, provide a link to the Creative Commons license, and indicate if changes were made. The Creative Commons Public Domain Dedication waiver (http://creativecommons.org/publicdomain/zero/1.0/) applies to the data made available in this article, unless otherwise stated. 
Her condition was worsening, and she was transferred to our hospital 7 days after her initial admission. Upon admission, her liver enzyme and creatine phosphokinase (CPK or CK) levels were high. She had no history of jaundice, pruritus, clay stools, melena, hematemesis, abdominal distension, or altered sensorium. She reported only an occasional small amount of ethanol intake and had not had sexual intercourse. The patient denied intake of indigenous medicine or intoxication. The patient did not report any past major surgeries, blood transfusions, or intravenously injected drug abuse prior to onset of the disease. Additionally, she did not report any history of diabetes, hypertension, tuberculosis, thyroid disease, trauma, exposure to industrial toxins or radiation, blood or blood component therapy, bleeding disorders, promiscuity, or similar complaints in the family or neighborhood.

Upon admission, her vital signs were as follows: body temperature, $37.2^{\circ} \mathrm{C}$; blood pressure, $110 / 72 \mathrm{mmHg}$; pulse, 75 beats/min; respiratory rate, 20 breaths/min; and oxygen

Table 1 Laboratory data upon admission

\begin{tabular}{|c|c|c|}
\hline Parameter & Recorded value & Standard value \\
\hline White blood cell count & $10,060 / \mu \mathrm{L}$ & $4500-7500 / \mu \mathrm{L}$ \\
\hline Neutrophils & $56.9 \%$ & \\
\hline Hemoglobin & $16.4 \mathrm{~g} / \mathrm{dL}$ & $11.3-15.2 \mathrm{~g} / \mathrm{dL}$ \\
\hline Hematocrit & $47.6 \%$ & $36-45 \%$ \\
\hline Platelet count & $12.6 \times 10^{4} / \mu \mathrm{L}$ & $13-35 \times 10^{3} / \mu \mathrm{L}$ \\
\hline International normalized ratio & 1.19 & $0.80-1.20$ \\
\hline Activated partial thromboplastin time & $33.4 \mathrm{~s}$ & $26.9-38.1 \mathrm{~s}$ \\
\hline C-reactive protein & $1.52 \mathrm{mg} / \mathrm{L}$ & $\leq 1.0 \mathrm{mg} / \mathrm{L}$ \\
\hline Total protein & $6.8 \mathrm{~g} / \mathrm{dL}$ & $6.9-8.4 \mathrm{~g} / \mathrm{dL}$ \\
\hline Albumin & $4.0 \mathrm{~g} / \mathrm{dL}$ & $3.9-5.1 \mathrm{~g} / \mathrm{dL}$ \\
\hline Total bilirubin & $0.8 \mathrm{mg} / \mathrm{dL}$ & $0.2-1.2 \mathrm{mg} / \mathrm{dL}$ \\
\hline Aspartate aminotransferase & 2082 U/L & $11-30 \mathrm{U} / \mathrm{L}$ \\
\hline Alanine aminotransferase & $1824 \mathrm{U} / \mathrm{L}$ & 4-30 U/L \\
\hline LDH & $4191 \mathrm{U} / \mathrm{L}$ & $109-216 \mathrm{U} / \mathrm{L}$ \\
\hline $\mathrm{LDH}-1$ & $12.9 \%$ & \\
\hline $\mathrm{LDH}-2$ & $15.2 \%$ & \\
\hline $\mathrm{LDH}-3$ & $13.3 \%$ & \\
\hline $\mathrm{LDH}-4$ & $18.2 \%$ & \\
\hline LDH-5 & $38.7 \%$ & \\
\hline CK & $3753 \mathrm{U} / \mathrm{L}$ & $40-150 \mathrm{U} / \mathrm{L}$ \\
\hline CK-MM & $99.4 \%$ & \\
\hline CK-MB & $0.6 \%$ & \\
\hline Blood urea nitrogen & $38.8 \mathrm{mg} / \mathrm{dL}$ & $8-20 \mathrm{mg} / \mathrm{dL}$ \\
\hline Creatinine & $0.8 \mathrm{mg} / \mathrm{dL}$ & $0.63-1.03 \mathrm{mg} / \mathrm{dL}$ \\
\hline Sodium & $134 \mathrm{mEq} / \mathrm{L}$ & $136-148 \mathrm{mEq} / \mathrm{L}$ \\
\hline Potassium & $5.2 \mathrm{mEq} / \mathrm{L}$ & 3.6-5.0 mEq/L \\
\hline Chloride & $106 \mathrm{mEq} / \mathrm{L}$ & 98-108 mEq/L \\
\hline Glucose & $108 \mathrm{mg} / \mathrm{dL}$ & $70-109$ mg/dL \\
\hline $\mathrm{pH}$ & 7.474 & $7.350-7.450$ \\
\hline Partial pressure of carbon dioxide & $34.9 \mathrm{mmHg}$ & $35.0-45.0 \mathrm{mmHg}$ \\
\hline Bicarbonate ion & $25.1 \mathrm{mEq} / \mathrm{L}$ & 23.0-28.0 mEq/L \\
\hline Lactic acid & $3.04 \mathrm{mmol} / \mathrm{L}$ & $0.44-1.78 \mathrm{mmol} / \mathrm{L}$ \\
\hline Anion gap & $11.9 \mathrm{mEq} / \mathrm{L}$ & $10.0-14.0 \mathrm{mEq} / \mathrm{L}$ \\
\hline
\end{tabular}

LDH lactate dehydrogenase, $C K$ creatine phosphokinase, $C K-M M C K$ in the skeletal muscle, $C K-M B$ CK in the blood 


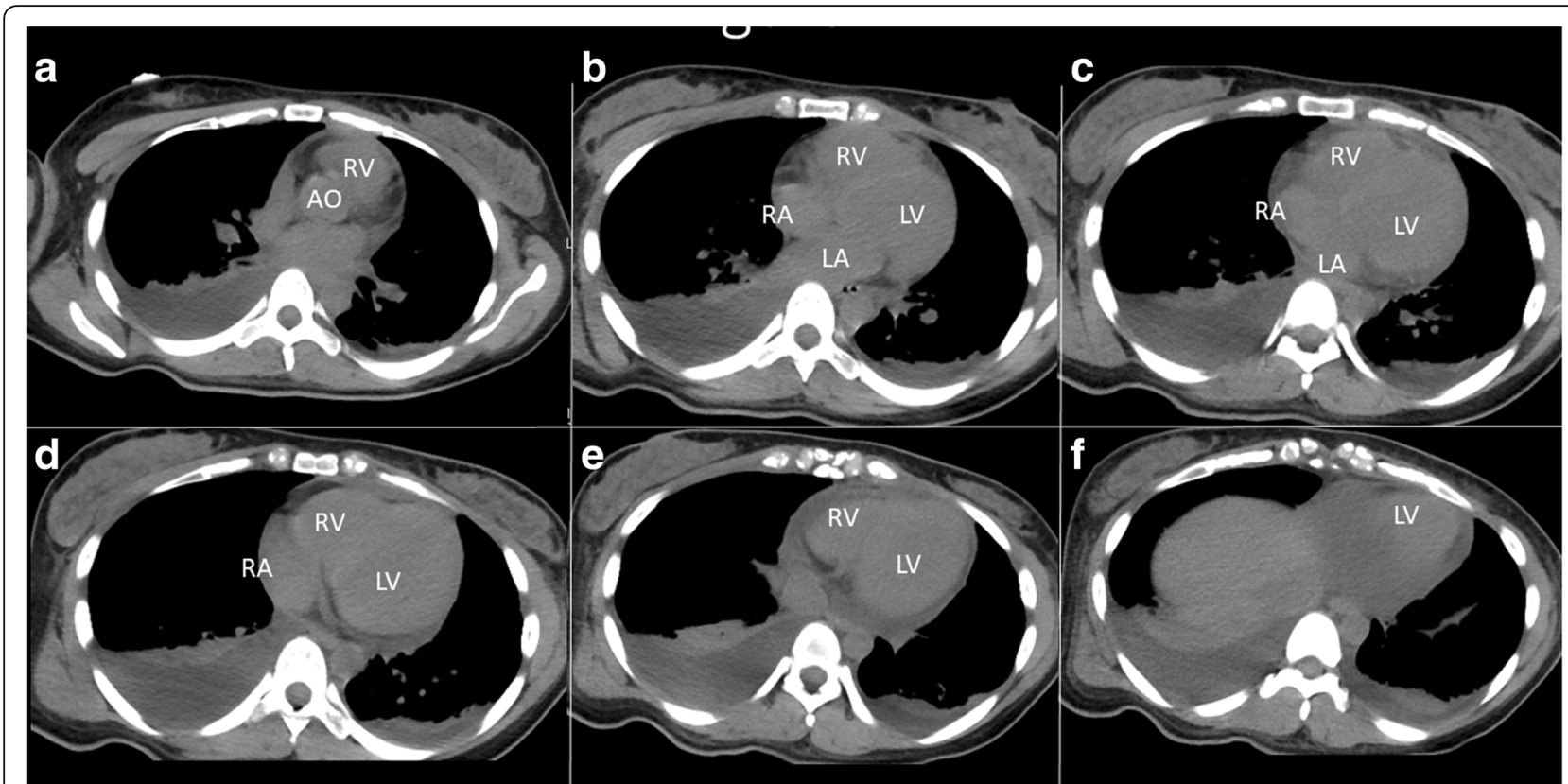

Fig. 1 Computed tomography of the heart. (a-f) Consecutive slices in horizontal view. Scans revealed a minimal pericardial effusion. Ao, ascending aorta; RA, right atrium; RV, right ventricle; LA, left atrium; LV, left ventricle

saturation, $98 \%$ on room air. A physical examination revealed mild enlargement of the liver, no pitting edema in both legs, and no coarse crackles over the lung fields. Laboratory findings are presented in Table 1.

Additionally, a chest radiography showed absence of pulmonary congestion, pleural effusion, and cardiomegaly. Electrocardiography was not performed on admission. Computed tomography of the chest (Fig. 1) and abdomen revealed minimal pericardial effusion, diffuse swelling, and an internal heterogeneous image in the

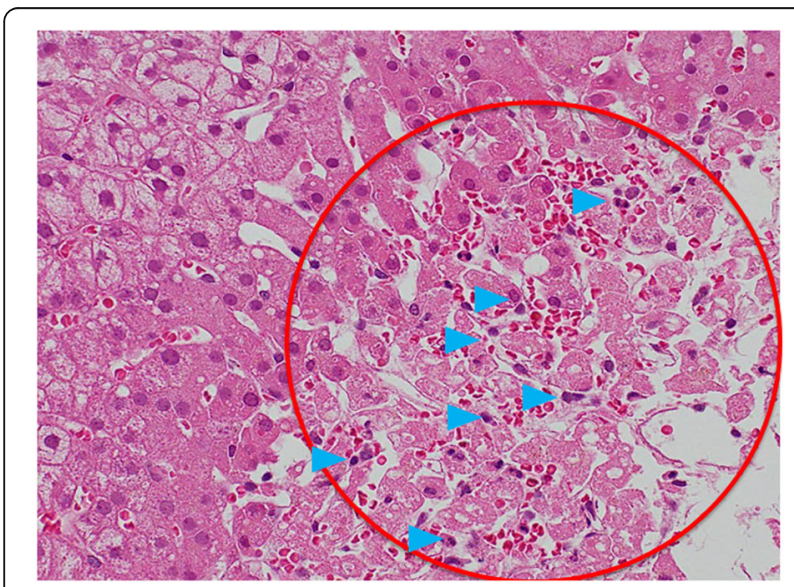

Fig. 2 Histopathology findings from the patient's liver (hematoxylineosin; original magnification $\times 200$ ). Parenchymal necrosis (red circle) and lymphocytic infiltration (blue arrows) were observed liver. These findings were compatible with acute hepatitis; therefore, we did not examine for cardiac function despite the presentation of pericardial effusion.

On the second day of hospitalization, we performed a liver biopsy, which showed parenchymal necrosis and lymphocytic infiltration (Fig. 2). On that same night, the patient was hypotensive, with a blood pressure of $80 / 65 \mathrm{mmHg}$, and her heart rate was elevated (113 beats/min). Physical examination revealed cyanosis of the lips, distended external jugular veins, pretibial edema in both legs, and coarse crackles over the lower bilateral lung fields.

Electrocardiography showed diffuse ST-segment elevation (Fig. 3). Her troponin I, CK level in the blood (CK-MB), and brain natriuretic peptide (BNP) were elevated (troponin $\mathrm{T}, 0.879 \mathrm{ng} / \mathrm{mL}$ [normal value: $\leq 0.016 \mathrm{ng} / \mathrm{mL}$ ]; CK-MB, $253 \mathrm{U} / \mathrm{L}$ [normal value: $\leq 5 \mathrm{U} / \mathrm{L}$ ]; BNP, $1513 \mathrm{pg} / \mathrm{mL}$ [normal value: $\leq 18.4 \mathrm{pg} / \mathrm{mL}])$. Chest radiography showed a normal cardiac size, pulmonary congestion, and pleural effusion in the right lung only (Fig. 4). Echocardiography showed a dilated, spherical ventricle with reduced systolic function (left ventricle ejection fraction [LVEF], 17\%) and pericardial effusion (Fig. 5).

Cardiac catheterization on day 3 revealed high pulmonary capillary wedge pressure $(22 \mathrm{mmHg})$ and a low cardiac index $\left(2.0 \mathrm{~L} / \mathrm{min} / \mathrm{m}^{2}\right)$. Coronary angiography showed no abnormalities. Endomyocardial biopsy (EMB) was performed via the right internal jugular vein, and five specimens were obtained from the right ventricle 


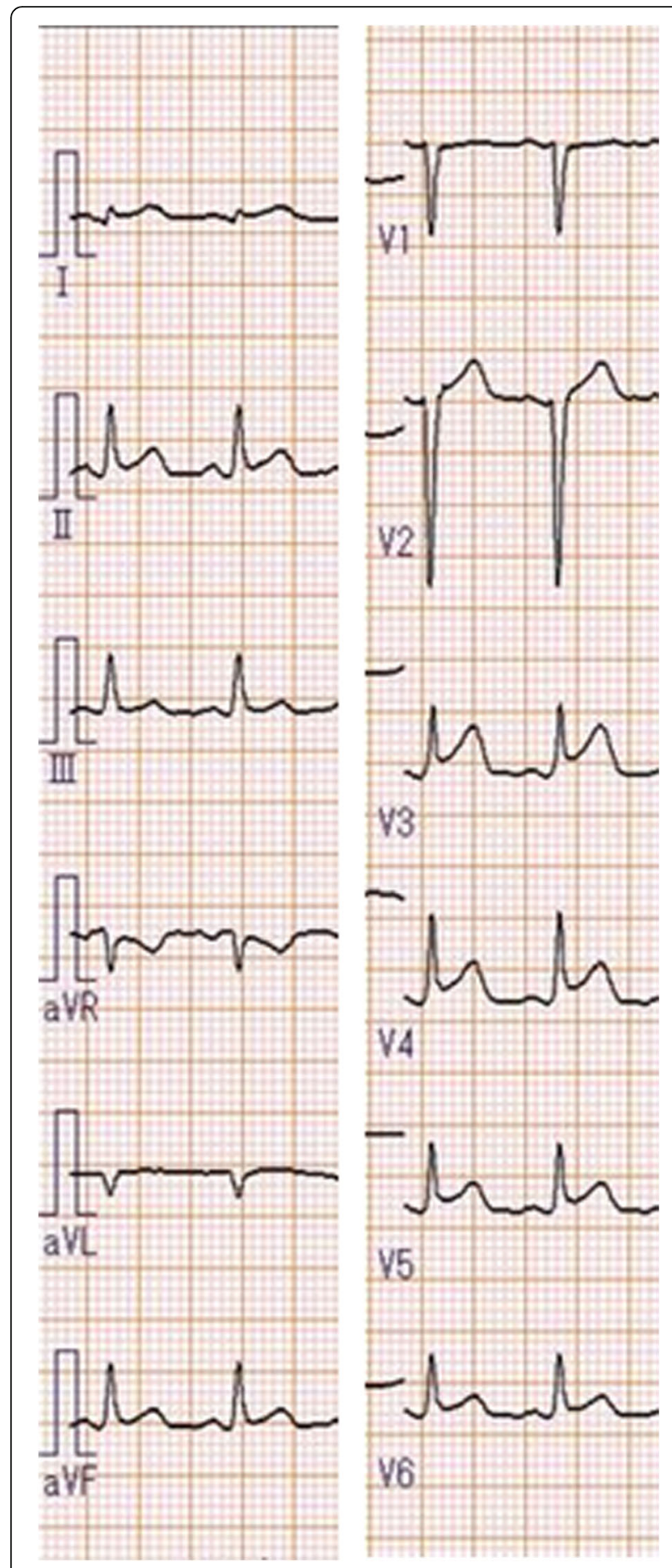

Fig. 3 Electrocardiogram finding from the patient. 12-lead electrocardiogram showed diffuse ST-segment elevations, with the exception of $\mathrm{V} 1$ and $\mathrm{aVR}$

side of the interventricular septum. Endomyocardial biopsy findings showed lymphocyte infiltration of the myocardium and intranuclear inclusions, which was confirmed as acute myocarditis (Fig. 6). In response,

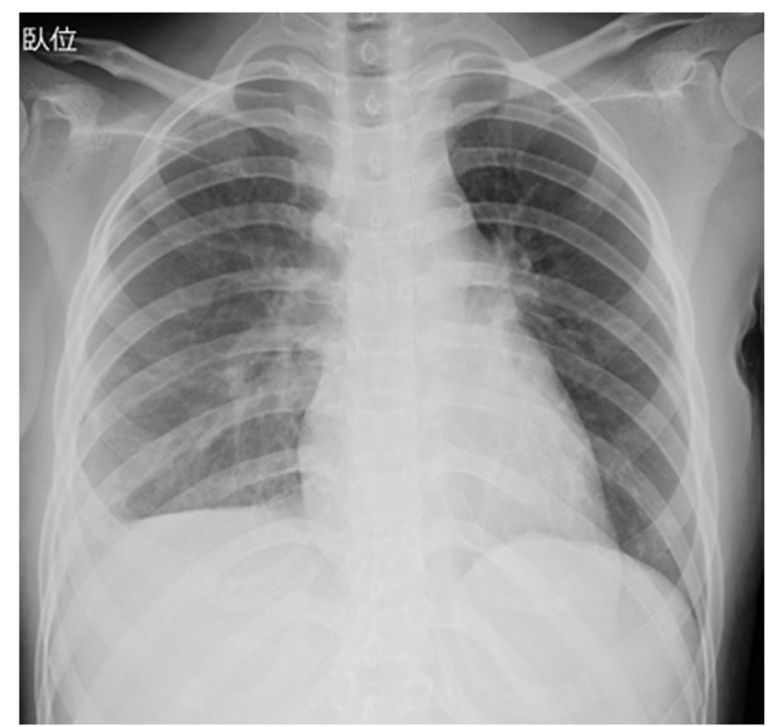

Fig. 4 Radiograph findings from the patient's chest. Chest radiograph showed a normal cardiac size (cardiothoracic ratio, 49\%), pulmonary congestion, as well as pleural effusion in the right lung only.

intravenous administration of dobutamine $(4 \mu \mathrm{g} / \mathrm{kg} / \mathrm{min})$ was started on day 3 . The patient's systolic blood pressure increased to approximately $100 \mathrm{mmHg}$ and stabilized, and dobutamine administration was gradually tapered off. On day 10, echocardiography showed normalization of LVEF to $71 \%$, dobutamine was stopped, and laboratory findings were almost normalized as follows: CPK, $143 \mathrm{U} / \mathrm{L}$ (standard values: 40-150 U/L); aspartate aminotransferase (AST), $36 \mathrm{U} / \mathrm{L}$ (standard values: $11-30 \mathrm{U} / \mathrm{L}$ ); and alanine aminotransferase (ALT), $278 \mathrm{U} / \mathrm{L}$ (standard values: 4-30 U/L). Laboratory findings on day 18 were normalized as follows: CPK, $123 \mathrm{U} / \mathrm{L}$; AST, $18 \mathrm{U} / \mathrm{L} ;$ ALT, $21 \mathrm{U} / \mathrm{L}$, and BNP, $18 \mathrm{pg} / \mathrm{mL}$. She was eventually discharged on day 19 of her hospital stay.

One serum sample for viral serological testing was collected before the EMBs were obtained. Follow-up serum samples were collected between 2 weeks, 1 month, and 6 months after the initial serum sample. The presence of HSV-specific immunoglobulin M (IgM) was detected upon admission to our hospital, increased at 2 weeks, and returned to normal 6 months later. Additionally, HSV-specific immunoglobulin G (IgG) increased from hospital admission to 2 weeks (Table 2). Other viral serologic tests, including HIV, were negative (Table 3). Based on this finding, we diagnosed the patient with acute myocarditis combined with hepatitis arising from HSV infection.

\section{Discussion and conclusions}

We described a rare case of combined myocarditis and hepatitis caused by HSV infection. To the best of 


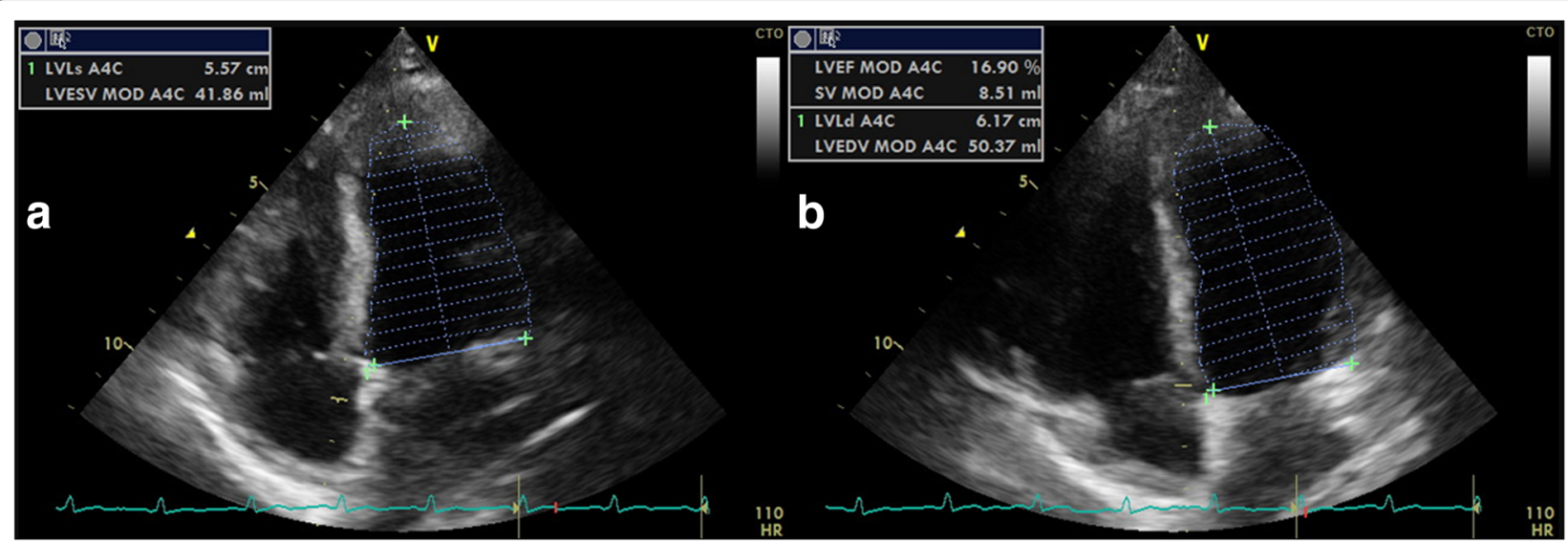

Fig. 5 Echocardiographic findings via apical four chamber views showing (a) end-systolic and (b) end-diastolic volumes. The echocardiography showed a dilated, spherical ventricle with reduced systolic function (left ventricle ejection fraction, 17\%) and pericardial effusion

our knowledge, this is the first case of combined myocarditis and hepatitis arising from HSV infection. In our case, both heart and liver biopsies were completed, and lymphocytic infiltration was detected in both biopsies.

Herpes simplex virus hepatitis is an uncommon complication of HSV infection, often leading to acute liver failure (ALF). It is thought to represent less than $1 \%$ of all ALF cases, and less than $2 \%$ of all viral causes of ALF [9]. Additionally, 24\% of HSV hepatitis cases were considered immunocompetent. The remaining patients were either pregnant $(23 \%)$ or immunocompromised from a previous solid organ, hematopoietic cell transplantation (30\%), or immunosuppressive agent (23\%) [10]. Symptoms are transient and mild in immunocompetent patients, and serious or fatal in immunocompromised patients [11].

Herpes simplex virus-induced myocarditis is also uncommon. Bowles et al. reported that polymerase chain reactions were positive for $\mathrm{HSV}$ in 5 of 624

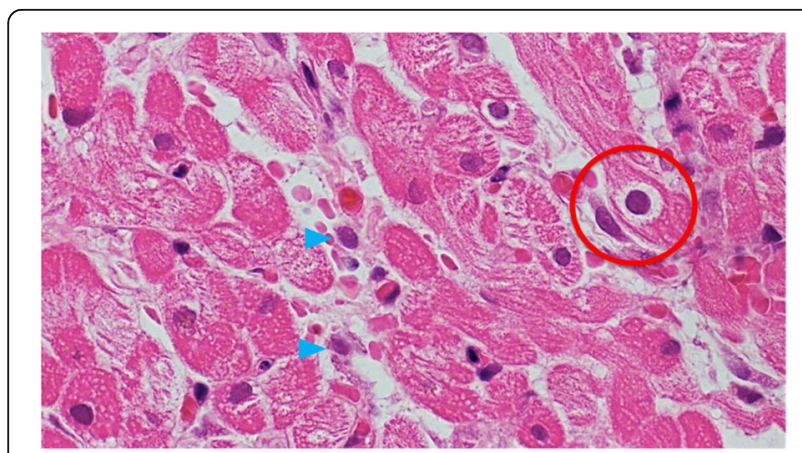

Fig. 6 Endomyocardial biopsy (hematoxylin-eosin; original magnification $\times 400$ ). Lymphocyte infiltration of the myocardium and intranuclear inclusions (red circle) were observed
$(0.8 \%)$ samples obtained from patients with myocarditis [12]. It has been reported that viral myocarditis may be combined with hepatitis, pancreatitis, nephritis, and encephalitis, but the majority of these reports used postmortem biopsies [6-8]. In our case, both heart and liver biopsies were completed, and lymphocytic infiltration was observed in both biopsies. Moreover, the pathological findings of the EMB specimen did not indicate ischemic hepatitis. We performed a biopsy from multiple organs of the patient, whereas previous reports generally obtained a pathology specimen via necropsy examination. Therefore, reports that obtained a pathology specimen during the patient's lifetime were rare. Although we could not confirm HSV in our pathological examination, it was serologically apparent that HSV was the cause of the infection.

It is often believed that liver enzyme elevation in a patient with myocarditis stems from ischemic hepatitis. In most cases, we cannot perform liver biopsy because of the patient's systemic condition and coagulation disorder; however, we must not forget that in a few instances, hepatitis is combined with myocarditis. Acute myocarditis may be combined with hepatitis, pancreatitis, nephritis, and encephalitis; therefore, it is important to determine whether other infectious lesions are present.

Table 2 Clinical course of herpes simplex virus-specific immunoglobulin $\mathrm{M}$ and immunoglobulin $\mathrm{G}$

\begin{tabular}{llllll}
\hline & Standard value & Admission & 2 week & 1 month & 6 month \\
\hline HSV-IgM & 0.7 & 11.72 & 13.27 & 10.06 & 0.20 \\
HSV-IgG & 1.9 & 8.0 & 19.4 & 20.6 & 12.0 \\
\hline
\end{tabular}

HSV herpes simplex virus, IgM immunoglobin $M, \lg G$ immunoglobin $\mathrm{G}$ 
Table 3 Laboratory data for hepatitis and causative infection agent

\begin{tabular}{ll}
\hline T-SPOT & Negative \\
\hline Antinuclear antibody & 40 \\
Anti-M2 Ab & Negative \\
HBs Ag & Negative \\
Anti-HBs Ab & Negative \\
Anti-HBC Ab & Negative \\
Anti-HCV Ab & Negative \\
HAV-IgM & 0.16 \\
HAV-IgG & 0.2 \\
HEV-IgA & Negative \\
EBVCA-IgM & 0.0 \\
EBVCA-IgG & 3.3 \\
EBNA-IgG & 2.1 \\
HSV-IgM & 11.72 \\
HSV-lgG & 8.0 \\
CMV-IgM & 0.16 \\
CMV-IgG & 0.2 \\
PVB19-IgM & Negative \\
Coxsackievirus & Negative \\
Adenovirus 3 & Negative \\
Adenovirus 7 & Negative \\
Influenza A/B antigen & Negative \\
Anti-HIV Ag/Ab & Negative \\
\hline Ab antibody, CMV cytomegalovirus, EBNA Epstein-Barr nuclear antigen, EBVCA \\
Epstein-Barr virus capsid antigen, HAV hepatitis A virus, HBC Ab hepatitis B core \\
antibody, HEV hepatitis E virus, HBs AG hepatitis B surface antigen, \\
immunodeficiency virus, HSV herpes simplex virus, IgA, IgG, IgM \\
immunoglobulin A, G, M; PVB19, parvovirus B19 \\
\end{tabular}

In conclusion, we presented a rare case of myocarditis combined with hepatitis that was caused by HSV infection. Acute myocarditis can have concurrence with hepatitis, pancreatitis, nephritis, and encephalitis; thus, determining the presence of other infectious lesions is necessary to provide appropriate treatment for the patient.

\section{Abbreviations}

ALF: Acute liver failure; ALT: Alanine aminotransferase; AST: Aspartate aminotransferase; BNP: Brain natriuretic peptide; CK-MB: CK level in the blood; CPK or CK: Creatine phosphokinase; CV: Coxsackievirus; EMB: Endomyocardial biopsy; HSV: Herpes simplex virus; IgG: Immunoglobulin G; IgM: Immunoglobulin M; LDH: Lactate dehydrogenase; LVEF: Left ventricle ejection fraction

Availability of data and materials

All data supporting our findings are contained within this published article.

\section{Authors' contributions}

TY managed the case and redaction and correction of the manuscript. TK assisted with redaction, correction, and reconstruction of the manuscript. MM, RN, and SK also assisted with clinical management of the case and correction of the manuscript. HA assisted with manuscript correction and redaction of comments from the illustrations. All authors read and approved the final manuscript.

Ethics approval and consent to participate

Ethics approval and consent for this case report were waived.

\section{Consent for publication}

Written informed consent was obtained from the patient for publication of this case report and accompanying images. A copy of the written consent is available for review by the Editor of this journal.

\section{Competing interests}

The authors declare that they have no competing interests.

\section{Publisher's Note}

Springer Nature remains neutral with regard to jurisdictional claims in published maps and institutional affiliations.

Received: 13 December 2017 Accepted: 21 June 2018

Published online: 03 July 2018

References

1. Cooper LT Jr. Myocarditis. N Engl J Med. 2009;360:1526-38.

2. Magnani JW, Dec GW. Myocarditis: current trends in diagnosis and treatment. Circulation. 2006;113:876-90.

3. Feldman AM, McNamara D. Myocarditis. N Engl J Med. 2000;343:1388-98.

4. Dec GW Jr, Palacios IF, Fallon JT, Aretz HT, Mills J, Lee DC, et al. Active myocarditis in the spectrum of acute dilated cardiomyopathies. Clinical features, histologic correlates, and clinical outcome. N Engl J Med. 1985;312: 885-90.

5. Mahrhodlt H, Wagner A, Deluigi CC, Kispert E, Hager S, Meinhardt G, et al. Presentation, patterns of myocardial damage, and clinical course of viral myocarditis. Circulation. 2006;114:1581-90.

6. Smith WG, Coxsackie B. Myopericarditis in adults. Am Heart J. 1970;80:34-46.

7. Akuzawa N, Harada N, Hatori T, Imai K, Kitahara Y, Sakurai S, et al. Myocarditis, hepatitis, and pancreatitis in a patient with coxsackievirus A4 infection: a case report. Virol J. 2014;11:3.

8. Martin AB, Webber S, Fricker FJ, Jaffe R, Demmler G, Kearney D, et al. Acute myocarditis. Rapid diagnosis by PCR in children. Circulation. 1994;90:330-9.

9. Schiødt FV, Davern TJ, Shakil AO, McGuire B, Samuel G, Lee WM. Viral hepatitis-related acute liver failure. Am J Gastroenterol. 2003;98:448-53.

10. Norvell JP, Blei AT, Jovanovic BD, Levitsky J. Herpes simplex virus hepatitis: an analysis of the published literature and institutional cases. Liver Transpl. 2007;13:1428-34.

11. Miyagawa K, Shibata M, Kumei S, Matsuhashi T, Hiura M, Abe S, et al. A case of resolved hepatitis B who was observed HBV viremia transiently during HSV hepatitis immediately after steroid pulse therapy. Kanzo. 2014;55:51-6.

12. Bowles NE, Ni J, Kearney DL, Pauschinger M, Schultheiss HP, McCarthy R, et al. Detection of viruses in myocardial tissues by polymerase chain reaction. Evidence of adenovirus as a common cause of myocarditis in children and adults. J Am Coll Cardiol. 2003;42:466-72.

\section{Ready to submit your research? Choose BMC and benefit from:}

- fast, convenient online submission

- thorough peer review by experienced researchers in your field

- rapid publication on acceptance

- support for research data, including large and complex data types

- gold Open Access which fosters wider collaboration and increased citations

- maximum visibility for your research: over $100 \mathrm{M}$ website views per year

At BMC, research is always in progress.

Learn more biomedcentral.com/submissions 